\title{
Contactless Automated Express Evaluation of Damages to a Car Body by Visual Parameters
}

\author{
M. Tarasova ${ }^{1)}$, N. Filkin'), R. Yurtikov ${ }^{1)}$ \\ ${ }^{1)}$ Kalashnikov Izhevsk State Technical University (Izhevsk, Russian Federation) \\ (C) Белорусский национальный технический университет, 2019 \\ Belarusian National Technical University, 2019
}

\begin{abstract}
Explosive development of computer technologies and their availability made it possible to extensively focus nowadays on emerging state-of-the-art technologies, digitalization, artificial intelligence, and automated systems, including in the field of road safety. It would be reasonable to implement some technical devices in this respect to remove human factor and automate some procedures completed at the scene of a road accident. Automatically filled up road accident inspection records and, mainly, diagrams of the accident will reduce time required for the examining inspector and remove human factor. Ultimately, an automated road accident data sheet is suggested to be established. To tackle the issues above requires a technique to determine whether the produced damages to the car body result from the same road accident. The fact remains that there are circumstances when even vehicle trace examination would not do the job, in case of multiple corrosive damage to the body. In view of the above, a technique designed to determine whether the damages produced are caused at the same point of time gains its ground. A technique for a time-related corrosion examination is offered herein to cut expenditures for diagnostics and expert examination of road accidents. That will also eliminate the matters of argument with respect to the road accident evaluation in court. Among added benefits of the technique are that it is simple, quick to implement, and requires no human involvement. It is a well-established fact that each chemical element or a mixture of substances has its own timeinvariant color attributes which allows to determine availability of one or another substance during corrosion of metal surfaces, by emission from the surface in question.
\end{abstract}

Keywords: road accident expert examination, artificial intelligence, color, corrosion, deformation of car body, RGB, car, vehicle, road safety

For citation: Tarasova M. A., Filkin N. M., Yurtikov R. A. (2019) Contactless Automated Express Evaluation of Damages to a Car Body by Visual Parameters. Science and Technique, 18 (6), 471-475. https://doi.org/10.21122/2227-1031-2019$18-6-471-475$

\section{Бесконтактная автоматизированная экспресс-оценка повреждений кузова автомобиля по визуальным параметрам}

\author{
М. Тарасова ${ }^{1)}$, Н. Филькин ${ }^{1)}$, Р. Юртиков ${ }^{1)}$ \\ ${ }^{1)}$ Ижевский государственный технический университет имени М. Т. Калашникова \\ (Ижевск, Российская Федерация)
}

Реферат. Благодаря бурному развитию вычислительной техники и ее доступности большое внимание в наше время уделяется новым современным технологиям, цифровизации, искусственному интеллекту и автоматизированным системам, в том числе и в сфере организации безопасности дорожного движения. В рассматриваемом аспекте было бы уместно внедрение технических средств, позволяющих исключить человеческий фактор и автоматизировать некоторые процессы на месте осмотра дорожно-транспортного происшествия (ДТП). Автоматизация процесса заполнения бланка протокола осмотра места ДТП и главным образом схемы ДТП позволит снизить затраты времени лица, проводящего осмотр, а также исключить человеческий фактор. По сути, представляется создание некого

\begin{tabular}{ll}
\hline Адрес для переписки & Address for correspondence \\
Тарасова Мария & Tarasova Maria \\
Ижевский государственный технический университет & Kalashnikov Izhevsk State \\
имени М. Т. Калашникова & Technical University \\
ул. Удмуртская, 139, & 139 Udmurtskaya str., \\
426069, г. Ижевск, Российская Федерация & 426069, Izhevsk, Russian Federation \\
Тел.: +7912 454-49-59 & Tel.: +7 912 454-49-59 \\
tarasovamariya@yandex.ru & tarasovamariya@yandex.ru
\end{tabular}


автоматизированного паспорта ДТП. Для решения таких вопросов просто необходимо создание методики, которая поможет определить, являются ли представленные повреждения кузова результатом одного ДТП. Ведь даже проведение транспортно-трасологической экспертизы не поможет в случае множественных повреждений кузова коррозией. Исходя из этого приобретает актуальность разработка методики, которая будет определять одновременность возникновения повреждений. Предлагается методика временной оценки процесса коррозии, что позволит сэкономить на диагностике и экспертизе дорожно-транспортного происшествия. При этом снимутся спорные вопросы оценки ДТП в судебных инстанциях. Дополнительными преимуществами данной методики можем считать простоту и скорость проведения экспертизы, отсутствие участия человека. Не секрет, что каждый химический элемент или смесь веществ имеет свои цветовые особенности, не изменяющиеся во времени. Наличие тех или иных веществ в процессе коррозии металлических поверхностей определяется по излучению от рассматриваемой поверхности.

Ключевые слова: экспертиза ДТП, искусственный интеллект, цвет, коррозия, деформация кузова автомобиля, RGB, автомобиль, транспортное средство, безопасность дорожного движения

Для цитирования: Тарасова, М. А. Бесконтактная автоматизированная экспресс-оценка повреждений кузова автомобиля по визуальным параметрам / М. А. Тарасова, Н. М. Филькин, Р. А. Юртиков // Наука и техника. 2019. Т. 18, № 6. C. 471-475. https://doi.org/10.21122/2227-1031-2019-18-6-471-475

\section{Introduction}

All road safety-related challenges are covered by the Federal Targeted Program "Enhanced Road Safety in the Years of 2013-2020" [1] aimed at provision of the measures to reduce number of road accidents and used for comprehensive approach thereto.

However, it is too early to suggest that the issue can be settled to the fullest extent. Prompt visit to the scene of road accident and immediate actions taken by a group of highway patrolmen allow to clear the traffic way quickly and efficiently, which in its turn directly contributes to recovery of the road traffic capacity. The key element in this case is to capture the scene of accident. Well-established inspection of the scene as performed by the officials improves efficiency of investigative activities. However, it might be difficult to inspect the scene of road accident to the highest standard due to a number of factors, including traffic flow density, road conditions, the fact that the scene may take a large portion of the traffic way, climatic conditions, time of day, availability of technical devices for comprehensive inspection and study of the traffic way, and, mainly, human factor. Performance of inspectors at the scene of road accident impacts investigation findings and defines the need to call for one or another technical vehicle expert examination.

Given the global development of state-of-theart technologies, an increasing attention is paid nowadays to emerging technologies, as well as artificial intelligence and automated systems. Road safety ranks high as well. That is the area where use of technical devices for automation of certain procedures completed at the scene of road accident is as relevant as ever and allows to remove human factor from the chain. This requires development of so called automated road accident data sheet, including automatically filled up road accident inspection records, which saves time of the examining inspector and gives an objective account of the situation.

There is a lot of techniques that can be used to determine whether a number of damages to the car body pertain to the same accident or there is a deceit under way. Alternatively, a vehicle trace expert examination might be considered. However, some factors, such as rust, might make the exert examination difficult. In view of the above, a technique designed to determine whether the damages produced are caused at the same point of time gains its ground.

The theoretical groundwork for the article is based on a number of studies dealing with road safety and technical expert examination of a car body [2-6], as well as atmospheric corrosion processes that take place therein $[7,8]$. The studies that deal with color reproduction and image analysis [9], as well as color of rust spots and conversion of color channel vector for digital photos [10-12] can also be highlighted.

Having analyzed all available scientific literature and periodicals, it can be safely assumed that the evaluation as to whether corrosive damage to the car body is caused at the same point of time is poorly covered.

\section{Body}

Moisture sets corrosion of metal surfaces in motion. As soon as condensate contacts with a metal surface, its rusting begins. Its color and structure in the points where the metal surface is exposed to water change. A spongy rough red or even brown film appears which means that hydrated ferric oxide or, in common terms, rust has formed. 
It is atmospheric corrosion that is the primary cause of damage to protective coating of a car body. The corroded surface is subjected to some processes that occur with time, resulting in change of ratio between hydrated iron compounds and oxides. Herewith, the layer corroded through and through changes its color which contributes to defining the corrosion stage and, therefore, time of the car damage.

Typical color changes in corrosion spots are covered in [13]. Comparing the color code of initial and corroded surfaces allows to find corrosion spots. As time passes, corrosion expands, additional spots appear, and the surface gains on color of corrosion products. To determine start-of-corrosion time, it is required to find a pattern in the way the color code changes between the initial and corroded surfaces.

Fig. 1 shows main corrosion products that are formed on surface of a car body. The additive color model RGB used illustrates that each chemical element has its own color.

Corrosion results in such substances formed on the surface, which combination is responsible for final color of the corroded surface. The color spectrum has a wide range, from yellow and orange to brown and even black. That poses a problem of finding a relation between the chemical substances formed on the surface, their concentration, and color of the corroded surface.

Among main corrosion chemical components are $\mathrm{FeO}(\mathrm{OH}), \mathrm{Fe}(\mathrm{OH})_{3}, \mathrm{Fe}_{2} \mathrm{O}_{3}$ and $\mathrm{Fe}_{3} \mathrm{O}_{4}$. There is no point to discuss others due to their high chemical reaction rate.

The above mentioned RGB color model is based on additive color mixing, meaning that it describes color synthesis. There are only three channels (red, blue, and green) that are used to obtain a wide range of color shades.

The technique is as follows. An image sensor of a camera device, having a form of a grid made of individual pixels, acts as a sensing element. Each pixel has three separate elements (channels) to cap- ture amount of light that strikes it and passes through red, green, and blue filters. Each channel features monochromatic perception, whereas its state varies from zero light perceived ( $0 \%$ ) to complete exposure $(100 \%)$. In particular, depth of the color perceived has 8-bit gradient, from black (0) to white (255). Therefore, color of an individual pixel can be defined based on combination of primary color gradients.

The sources $[14,15]$ suggest that color of the corroded surface of a car body changes with time. It means that different color of two spots of rust that is taken from the same metal surface but occurred at different times will bear evidence that different corrosion spots appeared in different circumstances, and it would be correct to say that the damages are caused under different conditions.

Accuracy of the system used is such that it will easily determine difference in time of the inflicted damages. It might be several days or even several years. The technique for processing the images of damaged elements of a car body is provided in [14]. Fig. 2 shows image expansion in color channels.

As can be seen from the above, establishing the time dependency of corrosion color may be used to determine time when the surface got damaged. The following technique will be quite of use. Let's carry out an experiment which will help define dependency of change in color of chemical elements and their mixtures on their concentration. Having provided identical illumination, main corrosion products with different concentrations are captured with a digital camera. A color mark with $18 \%$ of grey is used as a marker. This is so called grey card that will be used to provide the conditions required for exposure during taking photos in specific circumstances, involving setting of corrected white color balance under the conditions of mixed lighting so that the image will be further used as a white-grey color standard.

Now, let's distribute the obtained density values between three main channels of the objects under study (red, blue, and green).

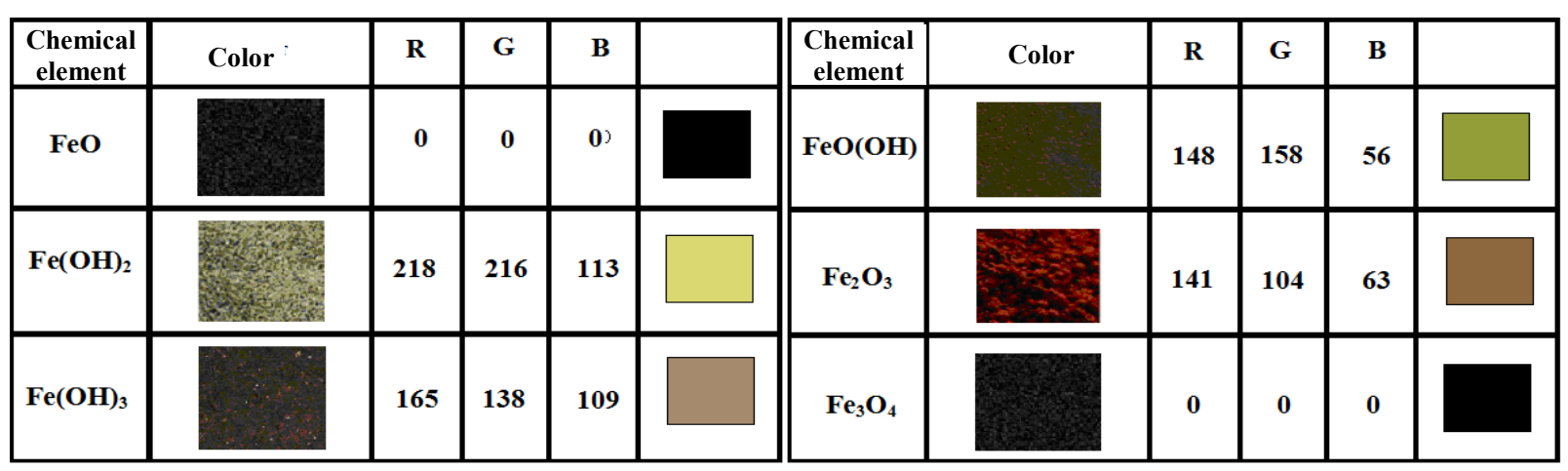

Fig. 1. Main corrosion products 


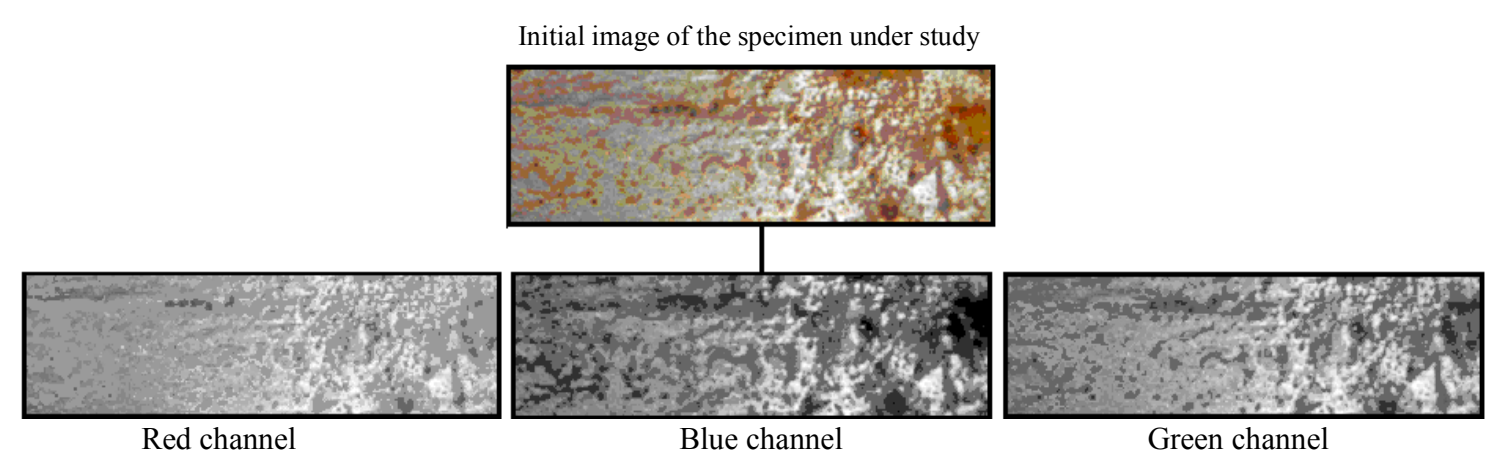

Fig. 2. Image expansion in three color channels

It can be concluded that color of corrosion products incrementally changes with time, which is accompanied by the change in density of color shades and, consequently, light reflected from corrosion products. This suggests that the damages inflicted are caused at the same point of time provided that color shades of corrosion spots and color density of rust in the damaged areas are identical.

Summing it up, a set of the evidences above can confirm whether damages to the car body are caused at the same point of time. This set can also be called a general population.

If corrosive damages to the car body pertain at least to two general populations, it can be said that rust did occur at the same time.

Now, let's discuss the case when two samples pertain only to one general population in more details. To do so, it is required to compare their mean values. Let's assume that both samples are independent and take the variant from among all admissible and possible ones where both variances are unknown but supposedly equal to each other. The selected variances of the first and the second populations will be used as an evaluation criterion. $S_{1 \delta}^{2}$ and $S_{2 \delta}^{2}$ are sample variances that are estimates of the same variance of the population $\sigma^{2}$.

There are good reasons to take critical values of the Student's distribution equal to 0.975 to ensure reliable results. Therefore, all damages to the car body, having such reliability will be confirmed to be inflicted as a result of the same road accident.

The procedure for determination as to whether damages to the car body are inflicted at the same point of time is provided below.

The areas of interest of the car body are captured with a digital camera. Their density gradient of primary colors is determined and added up. These resultant four color density samples (general populations) are processed so that sample mean values and sample variances are found for each general population. Two samples are formed for each general population, the first containing the values lower and the second containing the values higher than that of the respective general sample mean value. Then, sample mean values and sample variances are determined for all the samples obtained. A Student-Fischer test is used to check equality of sample mean values for each pair and that of sample variances. If the condition that the critical values corresponding to Student and Fisher distributions, determined from size of each sample and evaluation reliability, are higher for all respective pairs of sample populations is fulfilled, it can be concluded that the damages are caused at the same point of time.

Taking the proposed hypothesis and the technique as a basis, an express evaluation as to whether the damages are inflicted at the same time is developed.

Fig. 3 shows a flow chart for the express evaluation under discussion [16]. This method considers a car as a physical object, meaning that both damage spot and car model are taken into account. So are weather conditions (climate) and technical features of the vehicle.

During the examination, the object is captured with a camera, the corroded area is isolated with the use of software, and its color attributes are studied. After all color attributes are subjected to analysis, a conclusion as to whether the damages to the car body are caused at the same time is made, which allows to reveal deceit as a result of the expert examination and analysis of the road accident.

The technique is implemented with the special-purpose software intended for identification of time of damages. The result is taken as a basis of the judgment as to whether the damages pertain to the road accident under examination.

This software evaluates color shades of the damaged surface, which contributes to identification of corrosion spots and concluding about time of the damages (whether they are caused at the same point of time). 


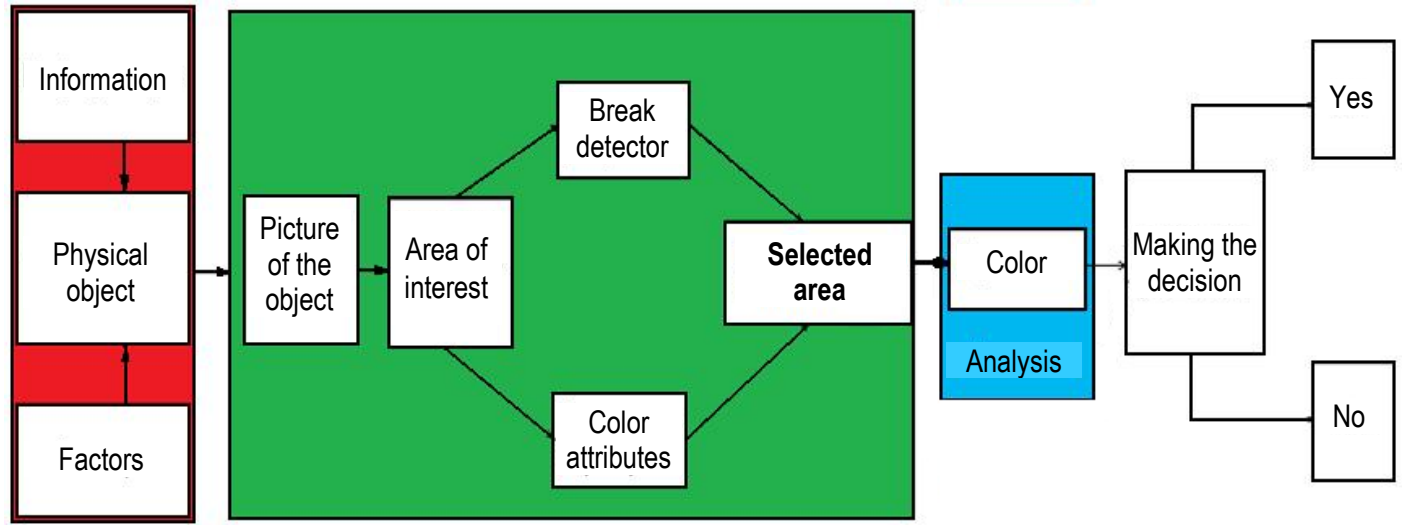

Fig. 3. Flow chart for express evaluation of corrosive damages to the car body

\section{CONCLUSIONS}

1. A technique for express evaluation is developed to be used during technical analysis of a car to determine whether the damages to the car body subject to corrosion are caused at the same point of time. This technique allows to define whether corrosion started at the same time, based on change in color of corrosion products. It may be used to reveal deceit during evaluation of consequences of road accidents.

2. An experiment was carried out to check efficiency of the technique for determination as to whether corrosion spots appeared on a car body at the same point of time. Herewith, experimental analysis shows that its accuracy reaches $95 \%$.

3 . The key advantages of the technique are that it is simple, quick to implement, and requires no human involvement. Neither steel grade, atmospheric composition, nor other similar factors that would reduce accuracy of other corrosion evaluation methods impact investigation results.

This publication has been developed within the framework of the project 15.06.01/18FNM "Wheeled and Tracked Vehicles" executed on the basis of Order of Rector of Federal State Budgetary Educational Institution of Higher Education Kalashnikov Izhevsk State Technical University No 1493 dated December 29, 2018 "About Grant-Based Support of Priority Research by Scholars of Kalashnikov Izhevsk State Technical University" with the financial support from Federal State Budgetary Educational Institution of Higher Education Kalashnikov Izhevsk State Technical University.

\section{REFERENCES}

1. The Order of the Government of the Russian Federation of October 3, 2013 No 864 "About the Federal Target Program "Increase of Traffic Safety in 2013-2020". Available at: https://base.garant.ru/70467076/.

2. Kapskii D. V., Azemsha S. A., Kuz'menko V. N., Mozalevskii D. V., Korzhova A. V., Polkhovskaya A. S., Ermakova N. S., Skirkovskii S. V., Artyushevskaya S. N. (2015) Road Safety Audit. Gomel, BelGUT. 428 (inRussian).

3. Kapsky D. V., Ryabchinsky A. I. (2016) Forecasting Method Conflict Zones Road Accident: Development and Improvement. Vestnik Moskovskogo Avtomobil'no-Dorozh- nogo Gosudarstvennogo Tehnicheskogo Universiteta $($ MADI) = Vestnik MADI, 44 (1), 107-113 (inRussian).

4. Molodtsov V. A. (2013) Vehicle Safety. Tambov, Tambov State Technical University. Available at: http://www.ipr bookshop.ru/63842.html (in Russian).

5. Ilarionov V. A. (1989) Traffic Accident Examination. Moscow, Transport Publ. 225 (in Russian).

6. Zotov B. L. (1991) Automotive Expertise in the Investigation of Traffic Accidents. Moscow, Gosyurizdat Publ. 178 (in Russian).

7. Berukshtis G. K., Klark G. B. (1971) Corrosion Resistance of Metals and Metal Coatings in Atmospheric Conditions. Moscow, Nauka Publ. 159 (in Russian).

8. Akimov V., Grinberg A., Malyshev G. (1977) Corrosion Measurement of Car Bodies. Avtomobil'nyi Transport, (4), 40 (in Russian).

9. Gonsales R., Vuds R., Eddins S. (2009) Digital Image Processing in MatLab. Moscow, Tekhnosfera Publ. 616 (in Russian).

10. Choi K. Y., Kim S. S. (2005) Morphological Analysis and Classification of Types of Surface Corrosive Damage by Digital Image Processing. Corrosion Science, 47 (1), 1-15. https://doi.org/10.1016/j.corsci.2004.05.007.

11. Pidaparti R. M., Aghazadeh B. S., Whitfield A., Rao A. S., Mercier G. P. (2010) Classification of Corrosion Defects in NiAl Bronze Through Image Analysis. Corrosion Science, 52 (11), 3661-3666. https://doi.org/10.1016/j. corsci.2010.07.017.

12. Medeiros F. N. S., Ramalho G. L. B., Bento M. P., Medeiros L. C. L. (2010) On the Evaluation of Texture and Color Features for Non-Destructive Corrosion Detection. EURASIP Journal on Advances in Signal Processing, (1). https://doi.org/10.1155/2010/817473.

13. Tarasova M. A. (2014) Optical Identification of Surface Corrosion Zones. Vestnik IzhGTU imeni M. T. Kalashnikova = Bulletin of Kalashnikov ISTU, (2), 39-40 (in Russian).

14. Kuznetsov N. P., Tarasova M. A., Yurtikov R. A. (2010) About One Way to Detect Fraud in the Staging of an Accident. Vestnik IzhGTU imeni M. T. Kalashnikova $=$ Bulletin of Kalashnikov ISTU, (3), 39-42 (in Russian).

15. Buravov D. N., Grakovich I. V., Kuznetsov N. P., Kuznetsov P. N. (2013) Certification of Accident Scene: Engineering Aspects. Izhevsk, Publishing house of IzhSTU named after M. T. Kalashnikov. 640 (in Russian).

16. Tarasova M. A. (2018) Express Method for Diagnosing Corrosive Damage to the Body. Intellektual'nye Sistemy $v$ Proizvodstve = Intelligent Systems in Manufacturing, 16 (2), 72-75 (in Russian). https://doi.org/10.22213/24109304-2018-1-72-75.

Received: 08.10.2019 Accepted: 29.11 .2019 Published online: 06.12.2019 